NBSIR 84-2884

\title{
Test Procedure for Armor-Piercing Handgun Ammunition
}

Prepared by the

U.S. DEPARTMENT OF COMMERCE National Bureau of Standards Law Enforcement Standards Laboratory National Engineering Laboratory

Washington, DC 20234

May 1984

Submitted to the

National Institute of Justice U.S. Department of Justice

QC Washington, DC 20531 



\section{TEST PROCEDURE FOR ARMOR-PIERCING} HANDGUN AMMUNITION

Prepared by the

U.S. DEPARTMENT OF COMMERCE

National Bureau of Standards

Law Enforcement Standards Laboratory

National Engineering Laboratory

Washington, DC 20234

May 1984

\section{Submitted to the}

National Institute of Justice

U.S. Department of Justice

Washington, DC 20531

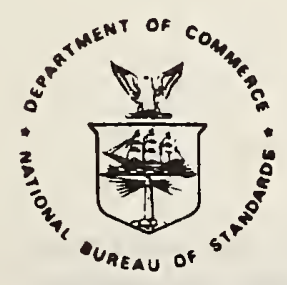

U.S. DEPARTMENT OF COMMERCE, Malcolm Baldrige, Secretary NATIONAL BUREAU OF STANDARDS, Ernest Ambler, Director 


\section{ACKNOWLEDGMENTS}

This report was prepared by the Law Enforcement Standards Laboratory (LESL) of the National Bureau of Standards under the direction of Daniel E. Frank, Protective Equipment Program Manager, and Lawrence $\mathbf{K}$. Eliason, Chief of LESL. Preliminary test method development was accomplished by Mr. Russell N. Prather, Chemical Systems Laboratory, Aberdeen Proving Grounds, U.S. Army. This work was sponsored by the National Institute of Justice, Lester D. Shubin, Standards Frogram Manager. 


\section{FOREWORD}

The Law Enforcement Standards Laboratory (LESL) of the ivational Bureau of Standards (NBS) furnishes technical support to the National Institute of Justice (NIJ), formerly the ivational Institute of Law Enforcement and Criminal Justice. The primary objective of the LESL program is to conduct research that will assist law enforcelient and criminal justice agencies in the selection and procurement of quality equipment.

LESL: (1) Conducts research to develop test methods that can be used to evaluate the variety of equipment used by the entire criminal justice system, (2) subjects existine equipment to laboratory tests for the purpose of establishing performance criterla, and (3) conducts research leading to tise development of several serles of docurients. Including national voluntary equipment standards, user guides, and technical reports.

This document is a law enforcement technology report developed by LESL as part of the NIJ Technology Assessment Program. The test method described in this report is the result of research conducted in response to the NIJ request to devise a method whereby handgun armunition could be evaluated to determine whether it should be classified as armor-piercing ammunition. Additional reports as well as other documents are being issued under the LESL program in the areas of protective equipment, communications equipment, security systems, weapons, emergency equipment. Investigative aids, vehicles, and clothing.

Technical comments and suggestions concerning this report are invited from all interested parties. They may be addressed to the Law Enforcement Standards Laboratory. National Bureau of Standards, Washington, DC 20234.

Lawrence K. Eltason, Chlef Law Enforcement Standards Laboratory 



\section{CONTENTS}

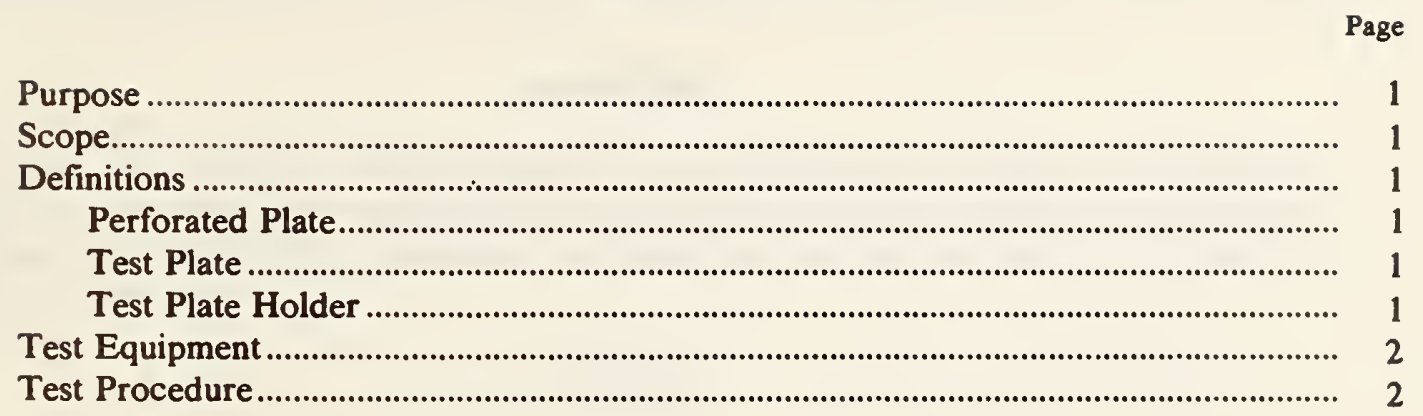





\section{TEST PROCEDURE FOR ARMOR-PIERCING HANDGUN AMMUNITION}

\section{PURPOSE}

This test procedure was developed as a discriminator between armor-piercing handgun ammunition and nonarmor-piercing handgun ammunition. The test procedure is intended to be used with a companion document, the industry standard for commercial handgun ammunition.*

\section{SCOPE}

The scope of this report is limited to specifying a test method that determines the penetration ability of handgun bullets. Since this procedure only measures the number of target plates which are perforated by a given bullet, other applicable documents must be consulted before the particular ammunition is labeled "Armor Piercing."

\section{DEFINITIONS}

\section{Perforated Plate}

A test target plate through which the light from a 60 -W light bulb will pass when the plate is held up to the bulb is deemed to be perforated. If a bullet passes partially through a plate and becomes lodged therein the plate is deemed to be perforated even though no light passes around the bullet.

\section{Test Plate}

One of a series of aluminum squares at which the handgun bullet will be fired.

\section{Test Plate Holder}

A framework similar to that shown in figure 1 that holds the test plates perpendicular to the initial line of flight of the bullet being tested.

\footnotetext{
-Supporting Arms and Ammunition Manufacturers' Institute, Inc. Voluntary industry performance standards for pressure and velocity of centerfire pistol and revolver ammunition for the use of commercial manufacturers. Volume II. ANSI Standard Z299.3 approved February 15, 1979. Available from the American National Standards Institute, Sales Department, 1430 Broadway, New York, NY 10018.
} 


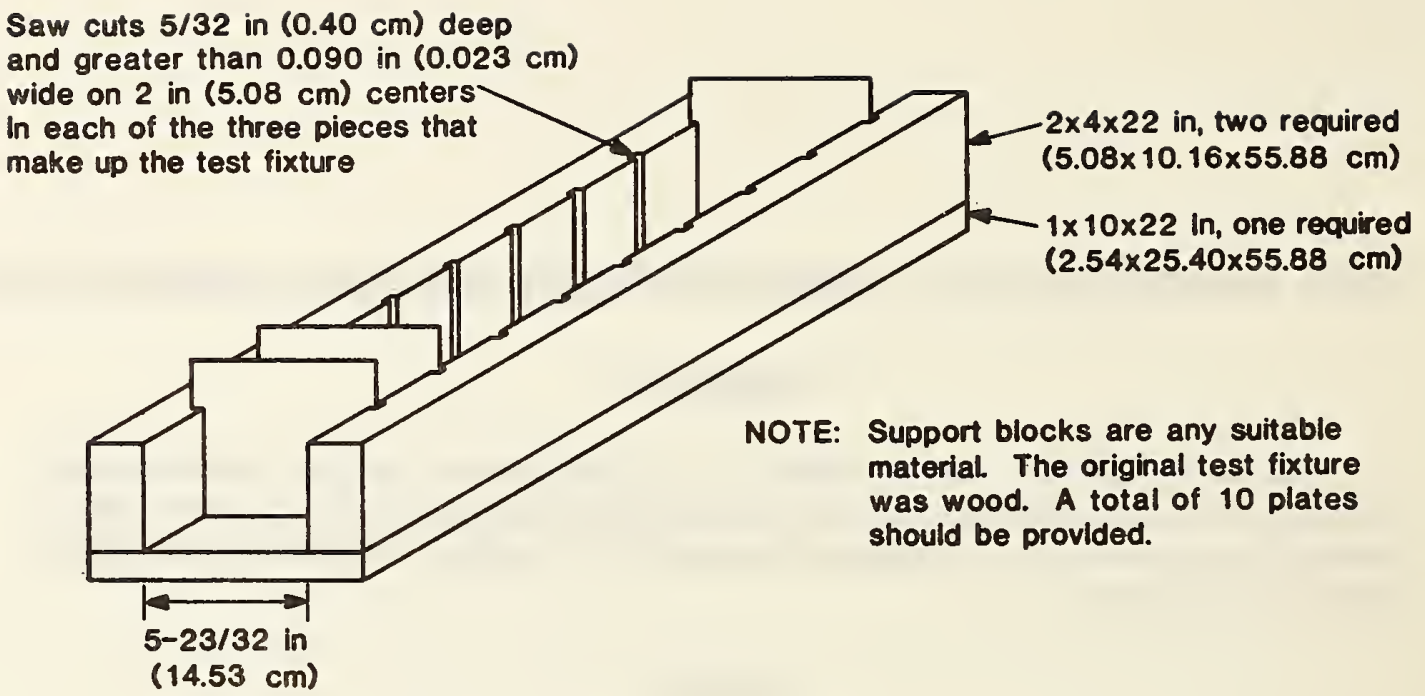

FIGURE 1. Test tanget.

\section{TEST EQUIPMENT}

- Test layout for instrumental velocity as prescribed in ANSI Z299.3* (see fig. 2).

- Universal receiver and mount.*

- Standard velocity and pressure barrels (nonvented).*

- Suitable test area with a backstop capable of safely stopping the bullets to be tested.

- Test target per figure 1.

- Square aluminum test plates, 2024-T3, $6 \pm 1 / 32$ in $(15.24 \pm 0.08 \mathrm{~cm})$ on each side by $0.090 \pm 0.004$ in $(0.023 \pm 0.010 \mathrm{~cm})$ thick.

\section{TEST PROCEDURE}

Set up the test equipment as prescribed in ANSI Z299.3.* Use the universal receiver mount to firmly clamp the universal receiver, with the barrel horizontal, in such a manner that the alignment of the weapon is not altered when it is discharged.

Position a sheet of cardboard behind the second screen of the velocity layout and fire a pretest round through the cardboard to determine the line of flight and the point of impact of the bullet. Place the test target in back of the sheet of cardboard, with the center of the first target plate in line with the bullet hole made by the test round, and then remove the cardboard. Fire one round of the ammunition to be tested in the test gun. Count the number of plates in the test target that are perforated by the bullet just fired.

The laboratory that employs this single-round procedure should repeat it based on a recognized sampling plan to assure statistical reliability in sampling and labeling as "Armor Piercing."

Note: Plates of the test target may not be reused if they underwent any impact during a previous test. 


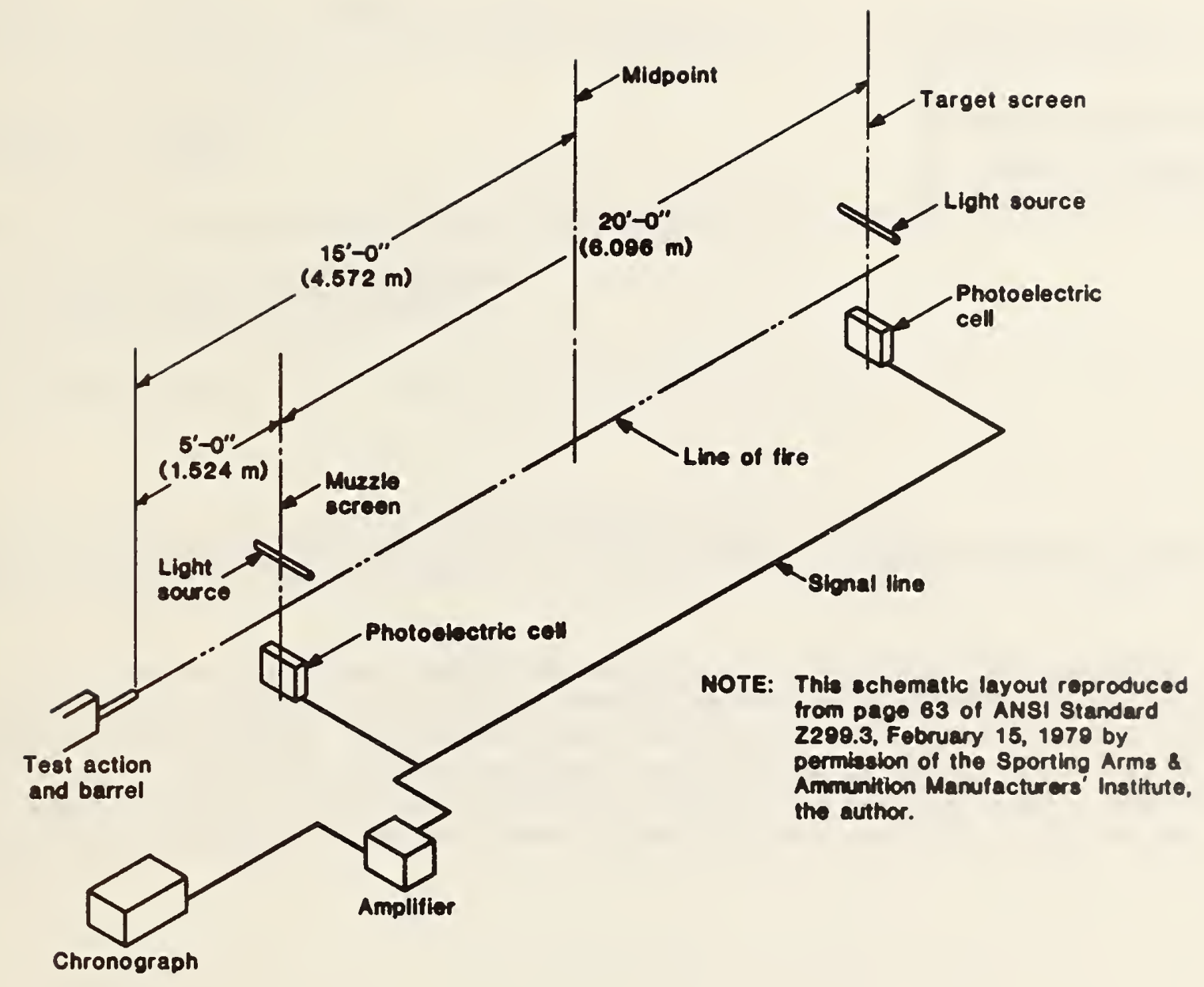

FIGURE 2. Schematic velocity test layout for instrumental velocity at 15 f $(4.572 \mathrm{~m})$ over 20 ft $(6.096 \mathrm{~m})$. 

4. TITLE AND SUBTITLE

Test Procedure for Armor-Piercing Handgun Ammunition

5. $\operatorname{AUTHOR}(S)$

Daniel E. Frank, Program Manager

6. PERFORMING ORGANIZATION (If joint or other than NBS, see instructions)

NATIONAL BUREAU OF STANDARDS

DEPARTMENT OF COMMERCE

WASHINGTON, D.C. 20234

7. ContracUGrant No.

9. SPONSORING ORGANIZATION NAME AND COMPLETE ADDRESS (Street, City.Stote, ZIP)

National Institute of Justice

U.S. Department of Justice

Washington, DC 20531

10. SUPPLEMENTARY NOTES

[Document describes a computer program; SF-185, FIPS Software Summary, is attached.

11. ABSTRACT (A 200-word or less factual summary of most significant information. If document includes a significant bibliography or literature survey, mention it here)

A test methou and test parameters are defined for ciscriminating between armor-piercing handgun ammunition and nonarmor-piercing handgun ammunition. A multi-plate aluminum test target is described where the number of plates perforated by the bullet, when fired at the test target out of an industry standard velocity gun, performs the discrimination between armor-piercing and nonarmor-piercing bullets.

12. KEY WORDS (Six to twelve entries; alphobetical order; copitallze only proper names; and seporote key words by semicolons) armor-piercing ammunition; bullets; handgun ammunition: penetration test: test methods; test plates

13. AVAILABILITY

X. Unlimited

$\square$ For Official Distribution. Do Not Release to NTIS

$\square$ Order From Superintendent of Documents, U.S. Government Printing Office, Washington. O.C. 20402.

14. NO. OF PRINTEO PAGES

9

15. Pilce

[X] Order From National Technical Information Service (NTIS). Springfield, VA. 2216I 


